\title{
Representaciones de serpientes en la iconografía mitraica
}

\author{
ana María Vázouez Hoys * \\ Julio MUÑoz García-VASO *
}

Desde finales del siglo pasado, en que se inicia el estudio sistemático del culto a Mithra, las representaciones de serpientes en la inconografía mitraica son objeto de una atención especial por parte de los investigadores. En el presente artículo estudiamos la presencia de la serpiente, como elemento iconográfico, en tres de las más genuinas imágenes del culto mitraico: 1. La Tauroctonia, escena cumbre del sacrificio del toro por Mithra (Figs. 1 y 2). 2. El "grupo trinario" león-crátera-serpiente (Fig. 3). 3. La figura de una divinidad, generalmente leontocéfala, rodeada por los anillos de una serpiente y dotada de alas, íntimamente relacionada con los Misterios de Mithra (Figs. 10-11).

1. F. Cumont para explicar el simbolismo de la Tauroctonía se siente inicialmente atraído por la hipótesis de K. B. Stark en el sentido de que, en su origen, esta representación sólo estuvo constituida por cuatro figuras: Mithra, el toro, el perro y el escorpión (K. B. Stark, 1865: 43). De esta manera quedaba justificado el valor dualistico que F. Cumont siempre atribuyó al mitraísmo: el escorpión, al que generalmente se le representa pinzando los genitales del toro, simbolizaría el Mal, que trata de destruir el origen de la vida en sus mismas fuentes, mientras que el perro, fiel amigo y compañero de Mithra, simbolizaría el Bien (F. Cumont, 1899: 189-192).

* Departamento de Historia Antigua. UNED. 


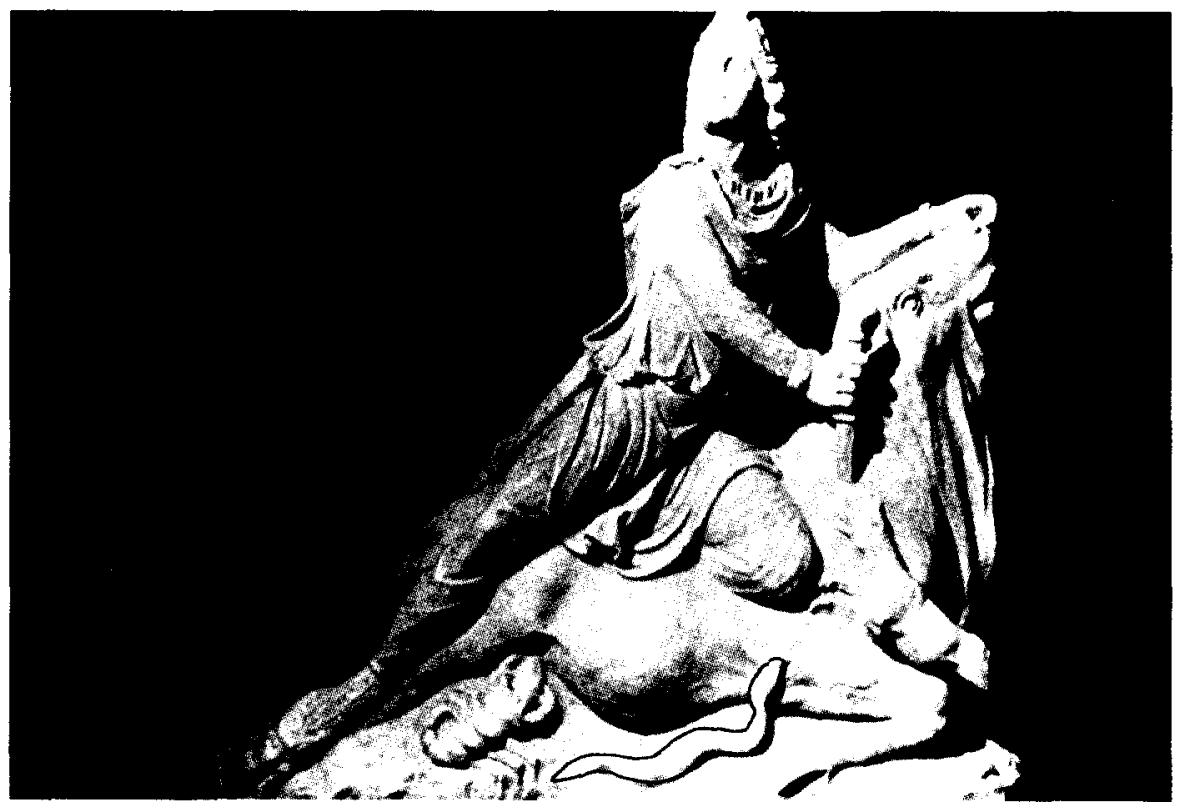

Fig. 1. Mithra tauróctono. Museo Arqueológico de Córdoba (España)

Pero a Cumont le preocupa el simbolismo de la serpiente en la Tauroctonia, y aun aceptando, en principio, que este animal pudiera no pertenecer a la escena y simbolizar simplemente la tierra (F. Cumont, 1899: $102-103$, n. 2-3), admite que en los cultos mistéricos la serpiente podría ser un símbolo benéfico (F. Cumont, 1899: 102 y 192, n. 4) e incluso desempeñar alguna función en la confrontación de los elementos, con el león (fuego) y la crátera (agua), figuras que con cierta frecuencia aparecen en esta misma escena ( $F$. Cumont, 1899: 103, n. 4; 1912: 68). También expresa sus dudas en cuanto a la posibilidad de que la serpiente simbolice el Mal (F. Cumont, 1899: 192, n. 4; 1912: 178) e incluso en un artículo aparecido póstumamente refleja las mismas dudas y llega a admitir que, tanto en un pequeño bajorrelieve del Mitreo de Neuenheim (Heidelberg) como en una pintura al fresco del de Dura-Europos (Siria), Mithras ephippos es «acompañado" en su jornada de caza por un león y una serpiente (F. Cumont, 1975: 188, n. 199).

Posteriormente, según $\mathrm{E}$. Will, en las diferentes tentativas de interpretación de la Tauroctonía sólo se evidenciaba un aspecto en el que los investigadores parecían haber llegado a un acuerdo: el significado de la serpiente (E. Will, 1955: 405). Por ello, cuando la representación de este 


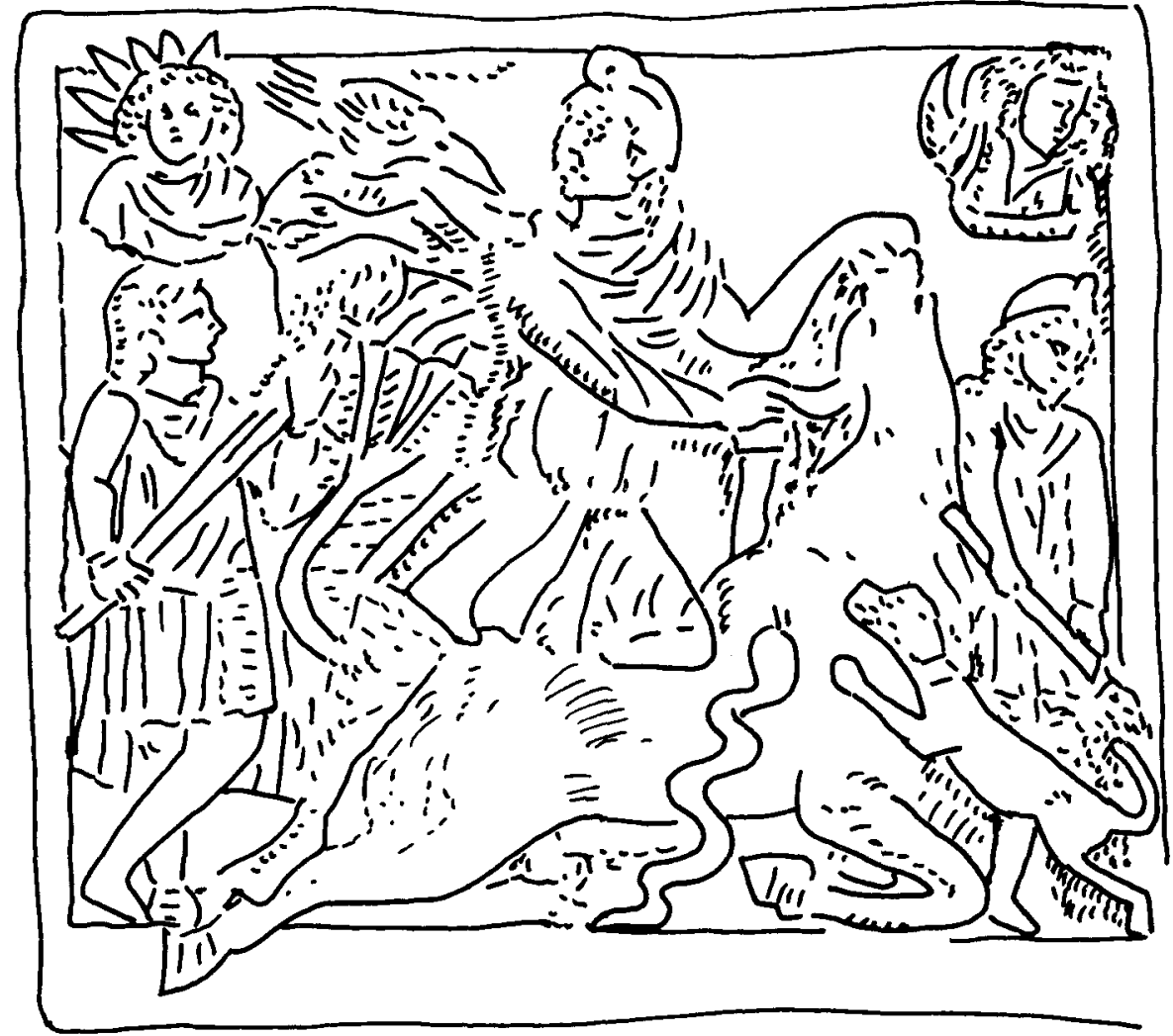

Fig. 2. Taurortonia mithraica. Relieve en marmol. Museo de Verona (Italia).

animal en la Tauroctonía vuelve a ser objeto de estudio en la más divulgada obra de $F$. Saxl sobre iconografía mitraica, el reptil conserva su significado chthónico ( $F$. Saxl, 1931: 20 y 60). Relacionada, desde los mismos orígenes, con la Tauroctonia, la serpiente, que dirige su cabeza hacia la herida del toro, como para beber la sangre que fluye de la misma, parece ofrecer, en principio, la mejor imagen de la tierra, fecundada por la sangre del animal regenerador. Saxl consideraba definitiva para la confirmación de esta teoría la presencia conjunta de Tellus - Terra Mater (E. Strong, 1937: 115) - y de la serpiente, en un relieve italiano, así como de esta misma divinidad, rodeada por los anillos de una serpiente, en otro relieve descubierto en Zagreb (Yugoslavia) (F. Saxl, 1931: 20 y 60). 
E. Will, por su parte, repara en que, partiendo de la ecuación: serpiente $=$ tierra, F. Cumont ya había establecido mucho antes este mismo simbolismo elemental, incluyéndolo además en el esquema general interpretativo de las otras figuras del conjunto tauróctono, como ya hemos señalado ( $E$. Will, 1955: 405).

A F. Cumont, una vez establecida la significación chthónica de la serpiente, sólo le restaba encontrar un simbolismo para los otros elementos. $\mathrm{Y}$ apoyándose en sendos pasajes de Porfirio, atribuyó al vaso la representación del agua (De Antro Nympharum, 18) y al león la del fuego (De Antro Nympharum, 15). Tierra, agua, fuego. ¿Pero cuál era el símbolo del cuarto elemento, el aire? Cumont sugeria algo muy poco verosímil: el aire estaba representado por el gorro de Mithra (F. Cumont: 1899: 116). Saxl rechazó la hipótesis de Cumont, precisamente por carecer, en su opinión, de una explicación más sólida de este cuarto elemento (F. Saxl, 1955: 65).

Por lo que respecta al "grupo trinario" león-crátera-serpiente» (Fig. 3) que con frecuencia se incluye en las tauroctonías y en otras escenas del ciclo mitraico, Will rechaza cualquier controversia interpretativa al respecto y aborda su estudio a partir de la figura que le resulta menos enigmática: la del león (E. Will, 1955: 406).

Para Will, la inseguridad interpretativa del esquema cumontiano reaparece cuando se aplica a otros monumentos, y cita, como ejemplo, un relieve de Tréveris en donde los cuatro elementos estarían representados por las siguientes figuras: vaso, león, rayo y globo terráqueo y roquedal (agua, fuego, aire y tierra). De hecho, un pilar figurado del Mitreo de Hedderheim muestra en su lado izquierdo el globo y el rayo, coronados por un águila con la inscripción Celum, y en su lado derecho, un personaje recostado, apoyado sobre una jarra invertida con la inscripción Oceanum. Pero, precisamente, en Tréveris - advierte Will- se ve la tierra simbolizada por un roquedal y no por la serpiente, cuya representación, sin embargo, no se ha omitido en el mismo monumento junto a los demás animales tradicionales de la Tauroctonía, aunque, en esta oca-

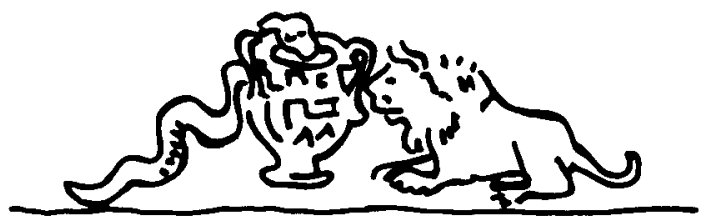

Fig. 3. Grupo trinario mitraico (Hedderheim, C 253) Will, E.: Le relief cultuel greco-romain, Paris 1955 fig. 72 pág. 405. 
sión, situándola debajo de una imagen de Mithra niño. Si a todo ello se añade - según Will- que la serpiente también "acompaña" a los citados Mithras ephippos de los mitreos de Dura-Europos y Neuenheim, aumentarán nuestras dudas para aceptar las proposiciones dualísticas de Cumont (E. Will, 1955: 406).

Saxl, por su parte, ya había rechazado todo simbolismo, señalando que el vaso, en torno al cual se enrosca la serpiente en numerosas representaciones, lejos de ser símbolo del agua, debía contener la sangre del toro inmolado por Mithra ( $F$. Saxl, 1955: 65). Pero tampoco las argumentaciones de Saxl parecieron concluyentes a Will (E. Will, 1955: 406).

2. Partiendo de tales premisas, Will estudiará la presencia de la serpiente no sólo en la Tauroctonía sino también en las otras dos representaciones iconográficas mitraicas antes mencionadas: el "grupo trinario»: león-crátera-serpiente y la figura de la divinidad leontocéfala alada, rodeada por los anillos de la serpiente.

Precisamente, Saxl también habia sugerido su propia explicación sobre el «grupo trinario». Según este autor, el arte religioso del Imperio conoció dos esquemas iconográficos que alcanzaron notable difusión: por un lado, los leones (o grifos) afrontados, representados a uno y otro lado de un vaso; por otro, las serpientes, agrupadas de la misma manera. $Y$ es a imagen de estos dos modelos como, según dicho autor, fue concebido el desigual grupo león-crátera-serpiente (Fig. 3) (F. Saxl, 1931: 60-61).

Para formular esta hipótesis, Saxl se apoyaba en la existencia anterior de la pareja león-vaso en las estelas danubianas. Pero ¿de dónde procede - se preguntaba - la asociación serpiente-vaso? Para responder a ello tuvo en cuenta el hecho, demostrado, de que en el culto mitraico se usaban vasos litúrgicos cuya panza o asas estaban rodeados por una o varias serpientes (F. Saxl, 1955: 60-61). Cinco de estos vasos, descubiertos en Colonia (Figs. 4, 5, 6 y 7) ya habían sido estudiados por $E$. Swoboda, que negaba, desde luego, su relación con el "grupo trinario" (E. Swoboda, 1937: 1-27). Estos mismos vasos han sido estudiados más recientemente por Ristow (G. Ristow, 1974: 21, núm. 13; 30, núms. 3537, láms. XIV-XV, figs. 15-17; XIX, fig. 22; XX; fig. 24; XXII, fig. 26; 1975: 61-63, fig. 64). Otros vasos litúrgicos mitraicos han aparecido en Eysses (Excisum), en Villeneuve-sur-Lot (Lot-en-Garonne) y en otros diversos lugares (localidades de los valles de l'Escaut y del Dendre, en Bélgica, Tournay y Aardenburg, en los Menapiens, en Blicquy, en los Nerviens, en Cambrai, que ahora se encuentran en el Museo de Chartreuse, etc.) $e$ incluso en la Península Ibérica, y han sido estudiados por diversos 


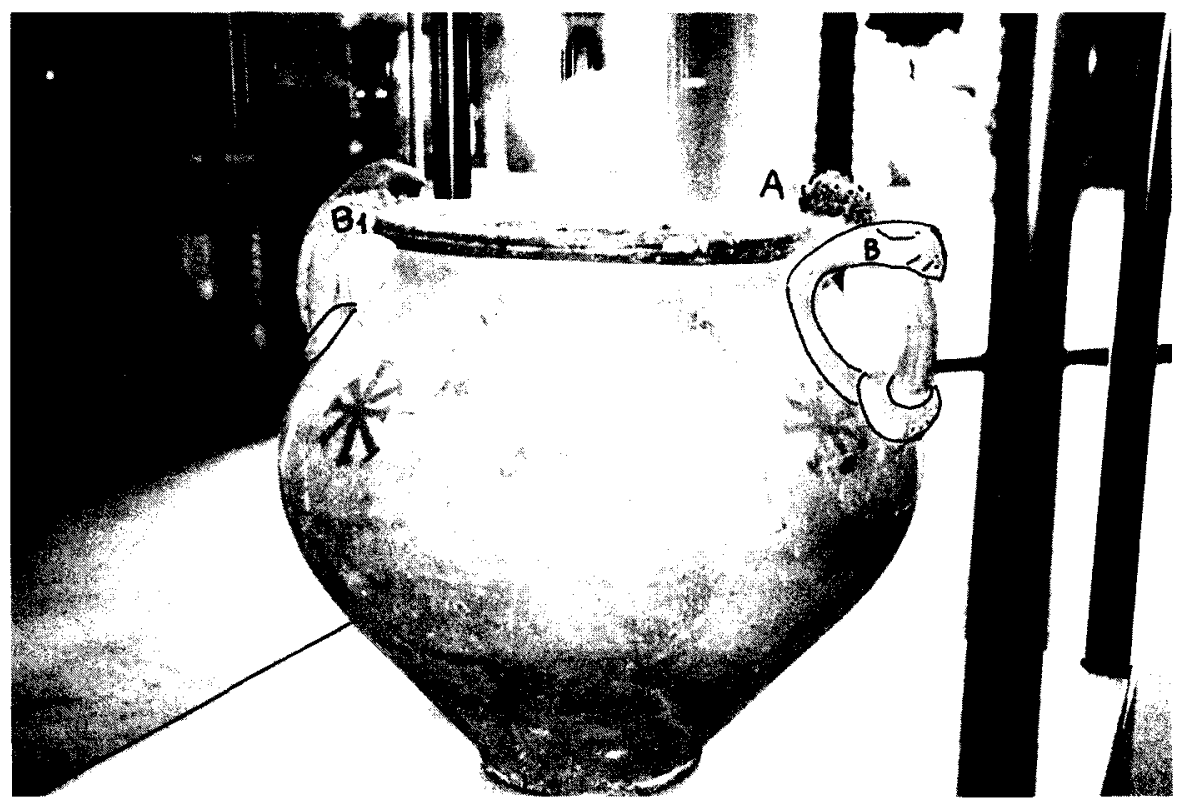

Fig. 4. Parte delantera de vaso mitraico, con Cautes y Cautopates. Sobre el asa derecha (A), león, y (B) (cabeza de serpiente). Sobre el asa izquierda $\left(B_{1}\right)$, cabeza de otra serpiente. Procede de Colonia (Alemania) de Zeughausstrabe/ Eeke. Kahenburg. En el Museo de Colonia, núm. inv. 58.289. (Foto A. Vázquez).

autores (M. Amand, 1975; R. Heldenbergh, 1976: 522 y figs. 3 y 6; R. Turcan, 1976: 196, núm. 5; 1977: 181-182; J. Muñoz, 1991: en prensa).

Para Will, el problema es todavía más complejo si se considera que, originariamente, en los monumentos renanos la serpiente que rodea con sus anillos el vaso es la misma que en la Tauroctonia dirige su cabeza contra el toro. $Y$ esta duda no permite proponer, según dicho autor, una explicación definitiva del significado del grupo león-crátera-serpiente, como hace Saxl, si bien, entiende que tal explicación deberá ser más sólida que la que proponía F. Cumont para este mismo conjunto (Will, 1955: 410). 


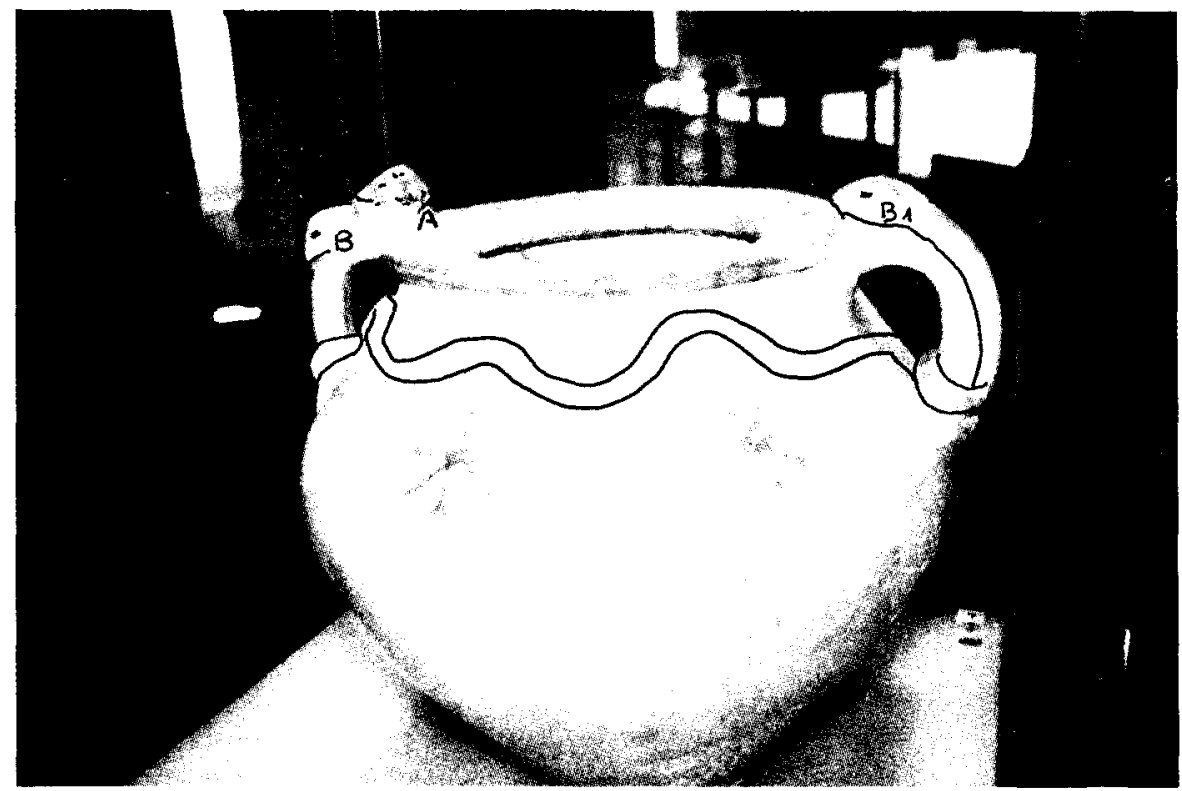

Fig. 5. Parte posterior del vaso anterior. Tanto las serpientes como el león llevan la misma numeración que en la foto núm. 5. (Foto A. Vázquez).

E. Will, en su estudio sobre este "grupo trinario", lo sitúa cronológicamente en el siglo III d.C., pero da por seguro que existía en el II a.C. o antes, ya que en él se fecha ya una representación posible del mismo (E. Will, 1955: 411, n. 1: “A Strasbourg, on voit sous le Taureau le vase au serpent; il n'existe pas trace du lion, mais il n'est pas impossible qu'il ait disparue").

Entre las conclusiones a las que llega $\mathrm{E}$. Will figura la de que, no sólo la Tauroctonia, sino todo el culto a Mithra, es manifestación de fenómenos "estrictamente helenísticos", y que, en consecuencia, el contenido de esta escena pertenece al fondo común del arte griego, cuyas formas definitivas se adquieren a partir de la época helenística y sólo son susceptibles de ser modificadas en detalles. $Y$ en el arte griego, ciertamente, es muy conocido el motivo iconográfico de la serpiente ya desde 


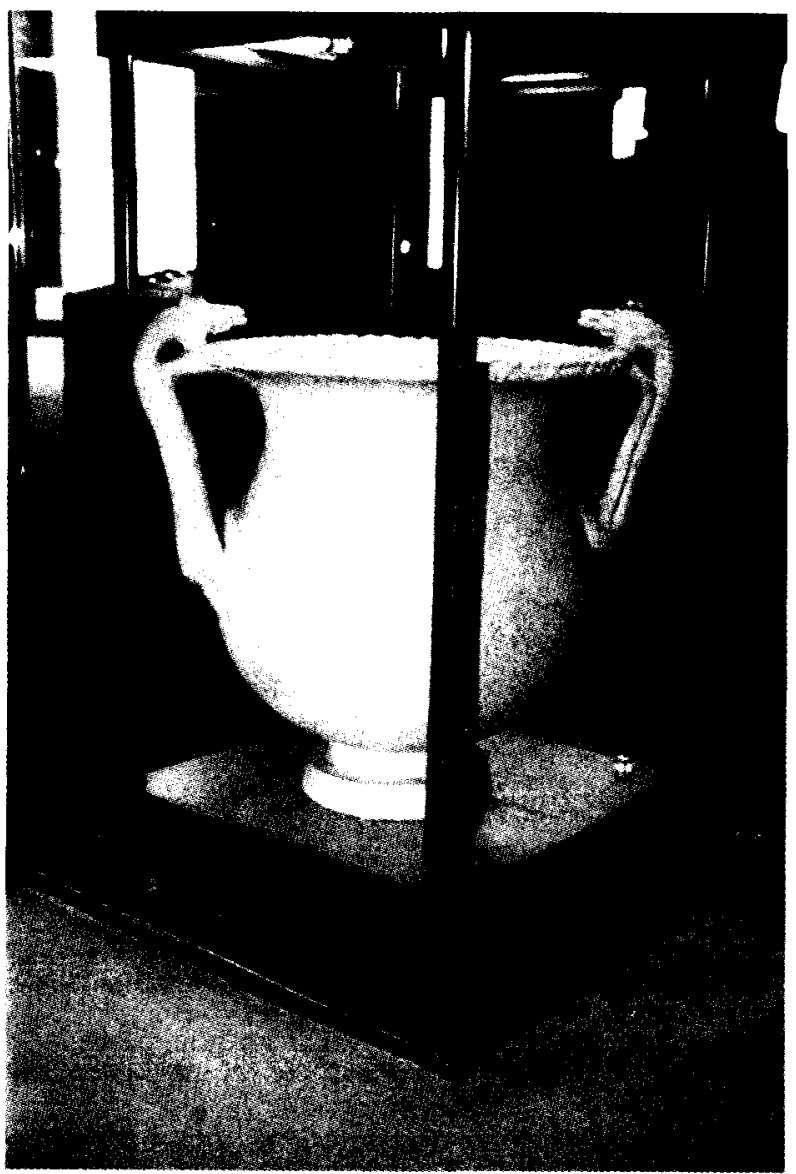

Fig. 6. Vaso mitraico. Museo de Colonia, Alemania núm. inv. 58.200. S. II-III. Procede de Colonia, Zeughaustraße/Ecke. (Foto A. Vázquez). 


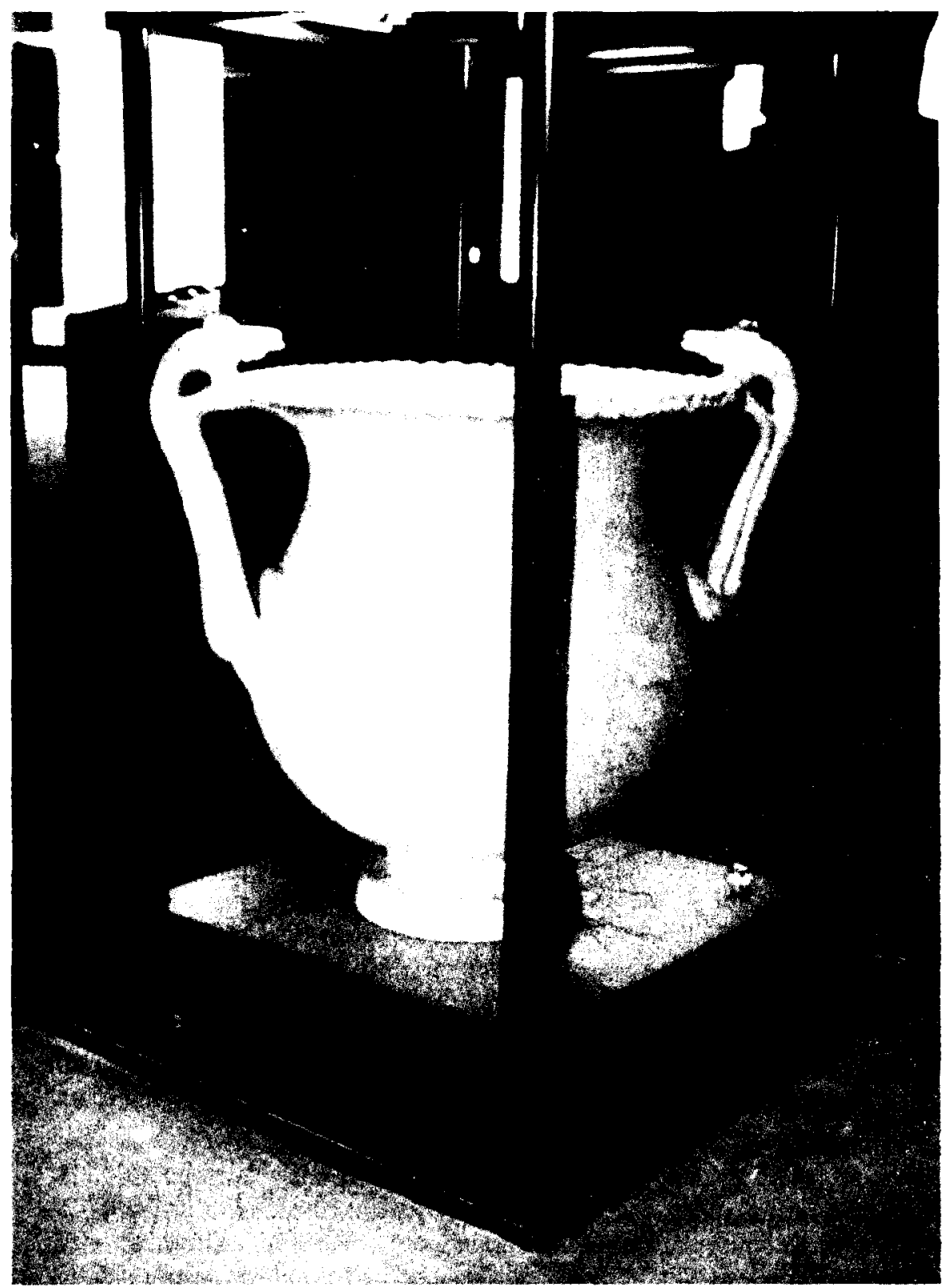

Fig. 7. Museo de Colonia (Alemania). Vitrina con los vasos anteriores abajo Arriba: Fragmento de vaso cultual. S. II d.C. Procede de Colonia, núm. inv. 3781: Sérpientes con penacho o cresta. (Foto A. Vázquez). 
épocas minoica y micénica, aunque se la represente a menudo en composiciones más libres, como en el caso de Hygia, el de Tellus - Terra Mater (E. Strong, 1937: 115) - e incluso el de Océano, que también aparece en algunos relieves mitraicos ( $E$. Will, 1955: 217).

Más recientemente, otros autores, sobre todo $M$. J. Vermaseren y L. A. Campbell, han vuelto a estudiar el simbolismo de la serpiente en la iconografía mitraica, poniendo también en duda su significado maléfico $y$, por consiguiente, el carácter dualístico de la escena tauróctona (M. J. Vermaseren, 1963: 70; L. A. Campbell, 1968: 17 ss.).

L. A. Campbell hace objeto de un estudio especifico la representación de la serpiente en la iconografía mitraica y de forma especial en la Tauroctonía, asegurando que en el Sureste de Europa la serpiente adopta, con frecuencia, en esta escena, una actitud más pasiva que el perro. Pero lo normal es que en las tauroctonías del Subtipo $\mathrm{C}$, según la conocida sistematización de este autor, la serpiente levante su cabeza hacia la herida sangrante del toro, y que lama, como el perro, la sangre. En estas tauroctonías, el reptil tiene una longitud proporcionada al conjunto de figuras, y es muy activo, especialmente en las pinturas al fresco (Fig. 2) (L. A. Campbell, 1954: 1-60; 1968: 15).

En los relieves del Subtipo DE, según la aludida sistematización, a la serpiente se la representa a la izquierda de la crátera mientras que el león aparece a la derecha de la misma. Y Campbell destaca que ésta es, precisamente, la posición de una Diosa Tierra reclinada representada en una Tauroctonía de Roma del Subtipo CDE, así como la de una figura de Océano del Mitreo de Santa Prisca, también en Roma (L. A. Campbell, 1968: 15).

Para Campbell es evidente que la serpiente, en la Tauroctonia, está relacionada, de algún modo, con el perro en cuanto a significado. En el relieve del Mitreo de Dura-Europos ambos animales atacan de frente al toro; pero lo habitual es que la serpiente repte paralelamente al toro en lugar de avanzar contra él como el perro. Tanto una como otro lamen la sangre que fluye de la herida del toro (L. A. Campbell, 1968: 16-17).

El citado autor también atribuye a la serpiente una simbología no derivada de la religión irania (al menos en versión zoroástrica). En el zoroastrismo, la serpiente ( $A z i)$ era una encarnación de Ahriman, el avéstico Angra Mainyu, y personificaba la codicia $(A z)$. En la Tauroctonia, la serpiente no es el ser maligno que engaña al hombre, haciéndole caer en la tentación, como en el relato bíblico, ni la encarnación del maligno Ahriman, el engañador (druj), sino un acompañante y ayudante del dios, igual que el perro. En tal sentido, la serpiente, como elemento iconográ- 
fico, pudo haber sido una elaboración greco-oriental con función complementaria a la del perro, elemento iconográfico iranio (L. A. Campbell, 1968: 19).

Hinnells, que ha analizado el pretendido carácter dualístico de la Tauroctonia en toda una serie de monumentos mitraicos romanos, llega a la conclusión de que "the Roman Mithraic reliefs depict the divine sacrifice which gives life to men, a concept which ultimately derived from Iran but which was expressed in terms meaningful to people living in the Graeco-Roman world" (J. R. Hinnells, 1975a: 309, n. 127). No existe, por tanto, según este autor, sentido dualístico alguno en la Tauroctonía, aunque su contenido vivificador proceda en último extremo de Irán y se exprese en términos significativos para los habitantes del mundo grecoromano.

Con la citada afirmación, Hinnells consumaba ante los participantes en el 1st. International Congress of Mithraic Studies, celebrado en Manchester, en 1971, el cisma científico que hoy separa a los investigadores de este tema, no obstante los buenos oficios conciliadores de ambas tendencias interpuestos posteriormente por algunos de los máximos especialistas mundiales en Estudios Mitraicos, sobre todo U. Bianchi e I. Sfameni Gasparro (U. Bianchi, 1979: 3-60; 1984: 2116-2134; I. Sfameni Gasparro, 1979: 299-348 y 397-410). De esta forma, el simbolismo de la serpiente se ha convertido, en el marco de los Estudios Mitraicos, en un elemento de discordia y de enfrentamiento entre los diferentes investigadores.

Para Hinnells, ni la serpiente ni el perro son exponente de la pretendida teología dualista atribuida a la Tauroctonia, ya que es imposible encontrar un solo relieve mitraico en el que, de manera clara, se pueda comprobar un enfrentamiento entre ambos animales (J. R. Hinnells, 1975a: 293). En algunos relieves, según el citado autor, faltan las dos figuras o solamente aparece la de la serpiente. En otros (Fig. 1) la serpiente se aleja del perro y se dirige hacia la crátera 0 , simplemente, reposa pasivamente, apartada de las demás figuras. $Y$ en la mayor parte de los relieves tauróctonos, tanto la serpiente como el perro buscan la sangre del toro, pero ignorándose mutuamente (J. R. Hinnells, 1975a: 293 y núms. 15-20).

Según Hinnells, es igualmente dudosa la suposición de que la serpiente simbolice el Mal (athe presupposition that the snake is a symbol of evil is equally doubtful»), rechazando, una vez más, cualquier connotación dualística, y citando como prueba de ello la presencia de la serpiente con cabeza radiada y cola lunar en un altar mitraico, junto al cueno y la espiga de trigo; en las escenas del nacimiento de Mithra; 
junto a símbolos de la fuerza generativa del nacimiento o renacimiento, como puedan ser la piña, el agua, el huevo; junto a la crátera en la escena del banquete místico, etc., y señalando que, en estas escenas, el reptil no tiene un simbolismo contrario al de las otras figuras, sino concomitante con ellas (J. R. Hinnells, 1975a: 293-294, ns. 21-25).

Como ejemplo, también recurre Hinnells al estudio antes citado de Swoboda sobre los vasos litúrgicos mitraicos decorados con serpientes. Swoboda habia llegado a la conclusión de que las serpientes podian haber desempeñado en ellos una función diferente a la desempeñada en los relieves (E. Swoboda, 1937: 1-27). Hinnells señala, con acierto, la imposibilidad de que la serpiente en un mismo contexto cultural, pueda simbolizar las fuerzas del Bien en los objetos rituales y la del Mal, en los relieves (J. R. Hinnells, 1975a: 294).

Un tercer argumento que, según Hinnells, resulta definitivo para rechazar el carácter maléfico de la serpiente en el contexto mitraico, lo constituyen muchos de los testimonios arqueológicos de este culto descubiertos en Ostia. Existe aquí un "Mitreo de las Serpientes" con representaciones pictóricas de estos animales en colores alegres, luminosos, semejantes a los de las pinturas báquicas, que simbolizan la vida. Y no es imaginable que tal simbolismo cromático lo hubiesen mantenido los devotos de Mithra si las serpientes hubiesen sido para ellos símbolos maléficos. En numerosos mitreos ostienses la serpiente se representa en los mosaicos de los pasillos centrales. En el "Mitreo de los Animales" vemos cuatro figuras; cuervo, escorpión, serpiente y toro, y nada indica que la serpiente y el escorpión simbolicen el mal, menos aún en cuanto que estas dos figuras están colocadas entre el toro y el cuervo y no opuestas a ellos. En el "Mitreo de las Siete Puertas", sobre el suelo, ante el altar, se ha representado una serpiente y un cuervo bebiendo en una crátera. Tampoco en este caso hay evidencias de enfrentamiento. En la entrada del "Mitreo de la Planta del Pie» aparecen las representaciones de un pie, del que toma el nombre este santuario, y de una serpiente (Fig. 8). Y aunque es difícil determinar su simbolismo, más lo es atribuir un carácter maligno a la serpiente (J. R. Hinnells, 1975a: 294, núms. 28-30, y 295, ns. 31-32).

Por si todavía existiera alguna duda sobre el simbolismo de la serpiente, el mencionado autor reitera no sólo su aparición en la pintura de Dura-Europos y en el relieve de Neuenheim, en los que Mithras ephippos cabalga en compañia de la serpiente y del león, sino el hecho de que éstos son los dos únicos animales no heridos por las flechas del divino cazador. Además es muy poco admisible, señala Hinnells, que Mithra, 


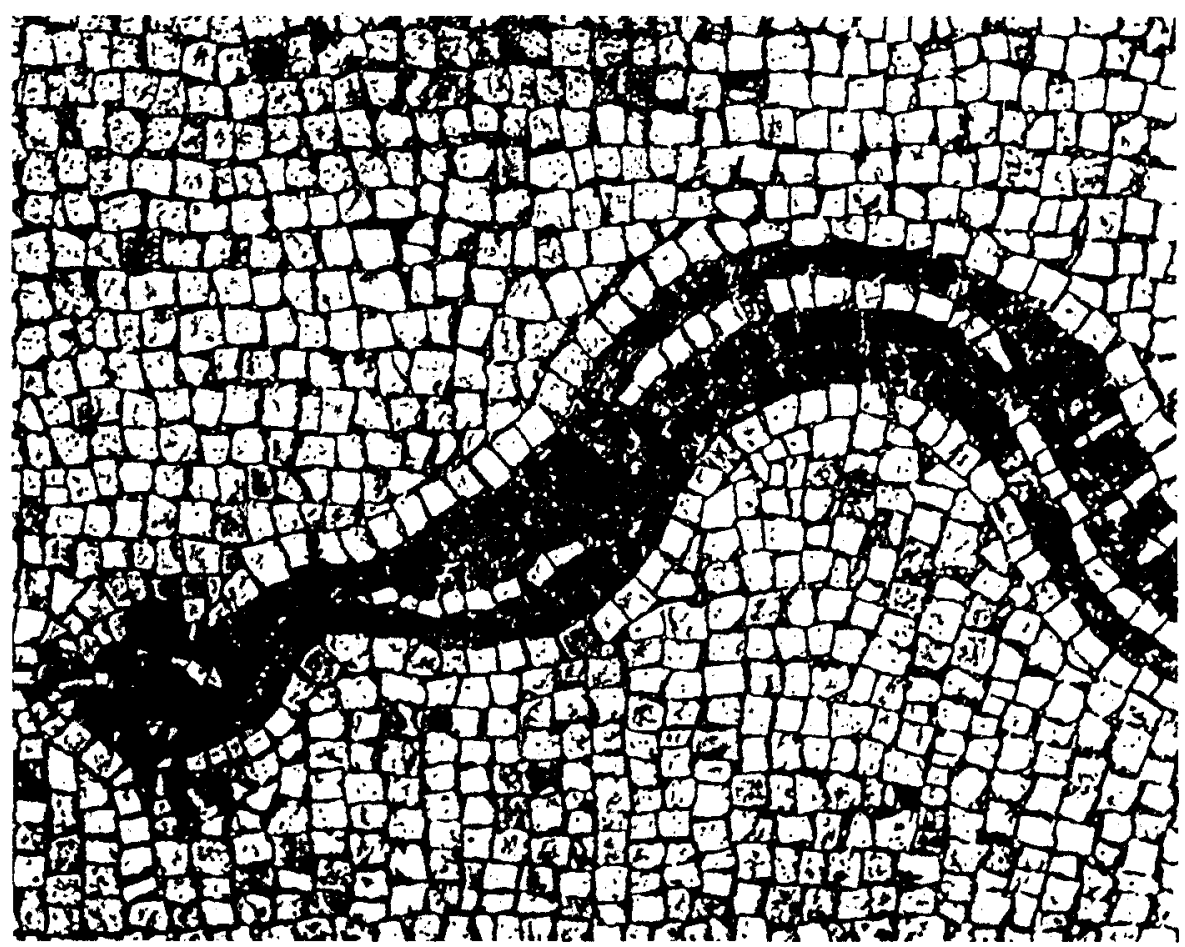

Fig. 8. Mosaico con serpiente. Mitreo de la Planta Pedis. Ostia (Italia).

campeón del Bien, saliese de caza en compañia del Mal (J. R. Hinnells, 1975a: 295).

De todo esto, el autor citado deduce que la serpiente debió ser considerada por los devotos de Mithra símbolo de una fuerza benéfica, dispensadora de vida («a benefical, life-giving force»), así como que esta reinterpretación de su función iconográfica coincide con el simbolismo anterior y contemporáneo greco-romano de este mismo animal, que ya constituia un motivo iconográfico generalizando y muy complejo («a common and very complex motif») (J. R. Hinnells, 1975a: 297 y 195, n. 34; A. M. ${ }^{a}$ Vázquez, 1981 passim).

Las características de la serpiente que determinaron la inclusión de su simbolismo en el citado contexto greco-romano fueron dos. En primer lugar, el hecho de que la morada de este animal es subterránea, circunstancia que facilita su asociación con la tierra y con la muerte; en segundo lugar, el hecho de que muda su piel, pudiendo rejuvenecer, teóricamente, cada año, lo que la convierte en símbolo de la resurrección y la vida eterna. A partir de estos dos hechos surge todo un rico simbolismo que 
sólo podemos dejar apuntado aquí. Su uso como representación de la tierra y del espíritu de la tierra es bien conocido y está profusamente atestiguado. Por esta misma razón, la serpiente se convierte en Grecia en símbolo de diversas divinidades asociadas a la tierra, como Céres, Kore y Deméter. Esta asociación con la tierra también puede ser la razón de su uso como símbolo de la muerte y del espíritu de la muerte. Asimismo, los conceptos de fertilidad y fecundidad están a menudo simbolizados por la serpiente. En este mismo contexto conceptual la serpiente también ha sido tomada como símbolo por varios dioses, principalmente por Asklepio (Fig. 9), dios de la salud, y además por Zeus, Sabazios, Hélios, Artemis, Hékate, etc... (H. Leisegang, 1955: 194-260; A. M. ${ }^{a}$ Vázquez, 1981: 167 ss.; M. Bru y A. M. ${ }^{a}$ Vázquez 1982: 305-311; L. A. Campbell, 1968: 17; E. Mitropoulou, 1975 passim).

La serpiente, también en este contexto, podría, por consiguiente, simbolizar una relación con un dios o incluso el mismo dios. Esta es la interpretación atribuida, por ejemplo, al ofidio, en los misterios traco-frigios de Sabazios por Clemente de Alejandría (Protrep., II, 16), en el año 190 a.C.:

"Zeus es tanto padre como seductor de Kore, y ha tenido relaciones con ella, habiéndose convertido en serpiente. Su identidad, sin embargo, fue descubierta. Los simbolos de los misterios sabazios para aquellos

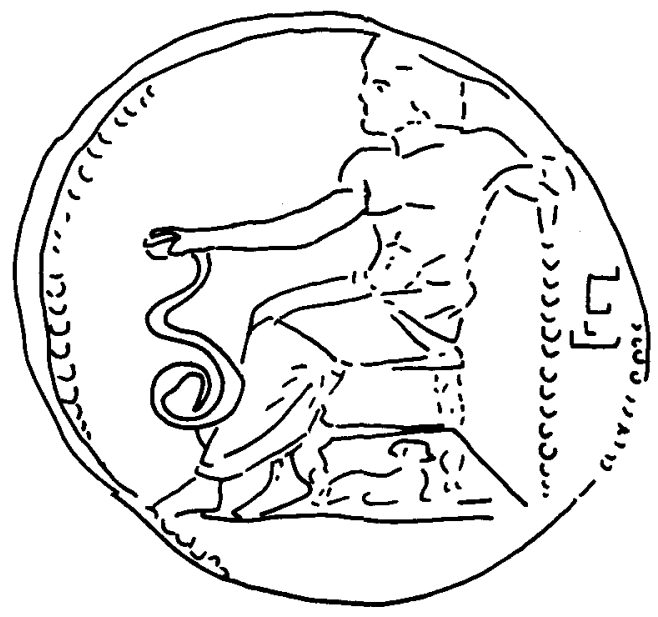

Fig. 9. Esculapio, dios de la medicina (Asklepios en Grecia) con la serpiente. Moneda griega. 
que se están iniciando en ellos es el dios sobre el pecho [ ], estando la figura de la divinidad, la serpiente enroscada, en torno al pecho del iniciado, prueba del desenfreno de Zeus. Pherephetta [hija de Zeus = Kore $=$ Persephone $]$ engendra un niño en forma de toro".

El citado poeta, pagano, por supuesto, escribe tambien

«El toro es padre de la serpiente

y la serpiente padre del toro." (Protrep. II. 16 y cfr. t. 6. EuRI. PIDES, Bac. 102-4, 697-8).

La serpiente, según Hinnells, podría, por tanto, tomarse también como signo de favor divino. Así, Tácito (Annals, XI, 10) recoge el rumor de que una serpiente había cuidado a Nerón durante su infancia. El hecho parece basarse en la creencia de que la presencia de una serpiente significaba el carácter más que humano (¿divino?) de una persona. Modernamente, Harrison señala que las diversas escenas que mostraban serpientes en los banquetes funerarios representaban la heroización del difunto (J. Harrison, 1963: 269 ss.).

En resumen, en el contexto greco-romano, la serpiente, especialmente en la Tauroctonía, podria simbolizar toda una variedad de fuerzas benefactoras: la tierra, los dioses, la relación con los mismos o su favor, la fertilidad, la salud, la fecundidad, el difunto y su heroización, etc... (Por solo señalar unas pocas caracteristicas, ya que los múltiples significados de la serpiente son casi infinitos y está presente en todas las culturas que conocemos, siempre representando una fuerza positiva excepto en algunos pasajes del Antiguo Testamento, o cuando es la adversaria de los dioses del cielo en diversas Teogonías o en el citado caso del zoroastrismo).

Por consiguiente, el significado de la representación de la serpiente en la Tauroctonía, de tener un fondo griego, habría que estudiarlo en este contexto. ¿Pero - nos preguntamos- realmente lo tiene?

Según Turcan, por ejemplo, se ha abusado de la idea de que la serpiente que repta sobre el suelo y sale de él tenga un carácter chthónico ( On a trop abusé de cette idée que le serpent qui rampe au sol et sort du sol est chthonien") (R. Turcan, 1974: 160). Y propone con sólidos argumentos la existencia de una identidad entre la serpiente y el fuego en el contexto cultual mitraico: “Mais entre l'ophidien et le feu surtout, il 
existe une relation fondamentale qui plonge ses racines au plus profond de la conscience humaine" (R. Turcan, 1974: 160).

3. Por lo que respecta al significado de la serpiente que rodea con sus anillos a la divinidad alada, generalmente leontocéfala, íntimamente relacionada con Mithra, e identificada, sobre todo, con Aion-ZervanChronos, dios del Tiempo Infinito, según unos autores, y con Ahriman, dios iranio del Mal y de las Tinieblas, según otros, también han sido muy diversas las interpretaciones formuladas. En Mérida (España) se han descubierto dos representaciones de esta divinidad, una de ellas leontocéfala, la otra, antropocéfala (Figs. 10, 11). En ambos casos, la figura aparece rodeada por los anillos de una serpiente (J. R. Mélida, 1914: 446-447, lám. V, 450-451, lám. V; A. García y Bellido, 1948: 326-327, figs. 7 en lám. 5, y 24, y 327-329, fig. 8 en lám. 6; 1967: 29-30, n. 1).

Según J. R. Mélida, el simbolismo que encierran estas imágenes es el siguiente: Zervan-Kronos representa el Tiempo; la serpiente que parece aprisionarle, el curso del Sol (J. R. Mélida, 1914: 451). A. García y Bellido, años más tarde, también señala que los anillos de la serpiente que envolvía el cuerpo de estas imágenes (en general en tres, cinco o siete vueltas, según los fatídicos números mágicos impares), representaban el curso del Sol en su eclíptica. Después de estudiar ambas representaciones, dice el citado autor que la misma serpiente que rodeaba el cuerpo de la estatua antropocéfala es la que vemos dando las mismas cinco vueltas alrededor del personaje leontocéfalo. La serpiente había de asomar sobre su rostro por encima de la cabeza leonina (A. García y Bellido, 1948: 326). Y, siguiendo a Mélida, describe también la imagen antropocéfala del dios: «El cuerpo va envuelto en cinco vueltas por una serpiente, que Macrobius explicaba ya como la imagen del curso del dios en la eclíptica, y que en otras figuras suele ser de siete vueltas o de tres (número impar). En la nuestra, la cabeza del reptil venía a apoyarse en la del dios, la cual debía de estar coronada de rayos broncíneos insertos en los agujeros que se perciben en el cabello alrededor de la frente" (A. García y Bellido, 1948: 328).

Aun no siendo rara la circunstancia de encontrarse ambas imágenes en un mismo santuario, como se ha señalado recientemente $(\mathrm{H}$. Von Gall, 1975: 511; M. Bendala, 1981: 291, n. 30), Bendala, que ha estudiado recientemente ambas figuras, llega a la conclusión, en el caso concreto de la representación antropocéfala, de que no se trata ni de Aion ni de Ahriman, sino del mismo Mithra saxigenus (M. Bendala, 1981: 295-296, figs. 4-7; 1982 : 108, figs. 4-7). Desde el punto de vista del presente artículo, lo más importante de la hipótesis de Bendala es el papel decisivo que la serpiente juega en ella. 


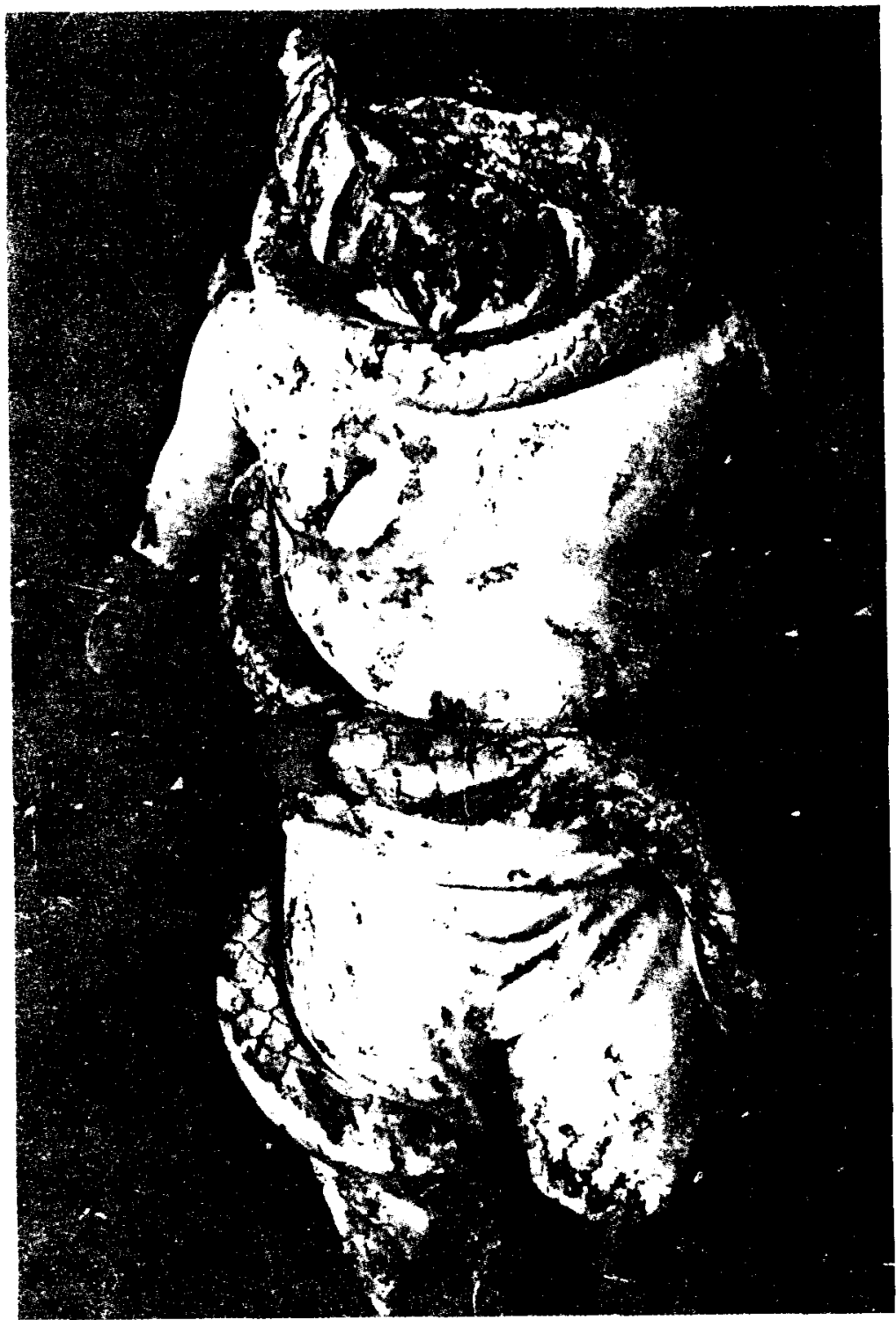

Fig. 10. Aion leontocéfalo. Museo Arqueológico de Mérida (Badajoz, España). 


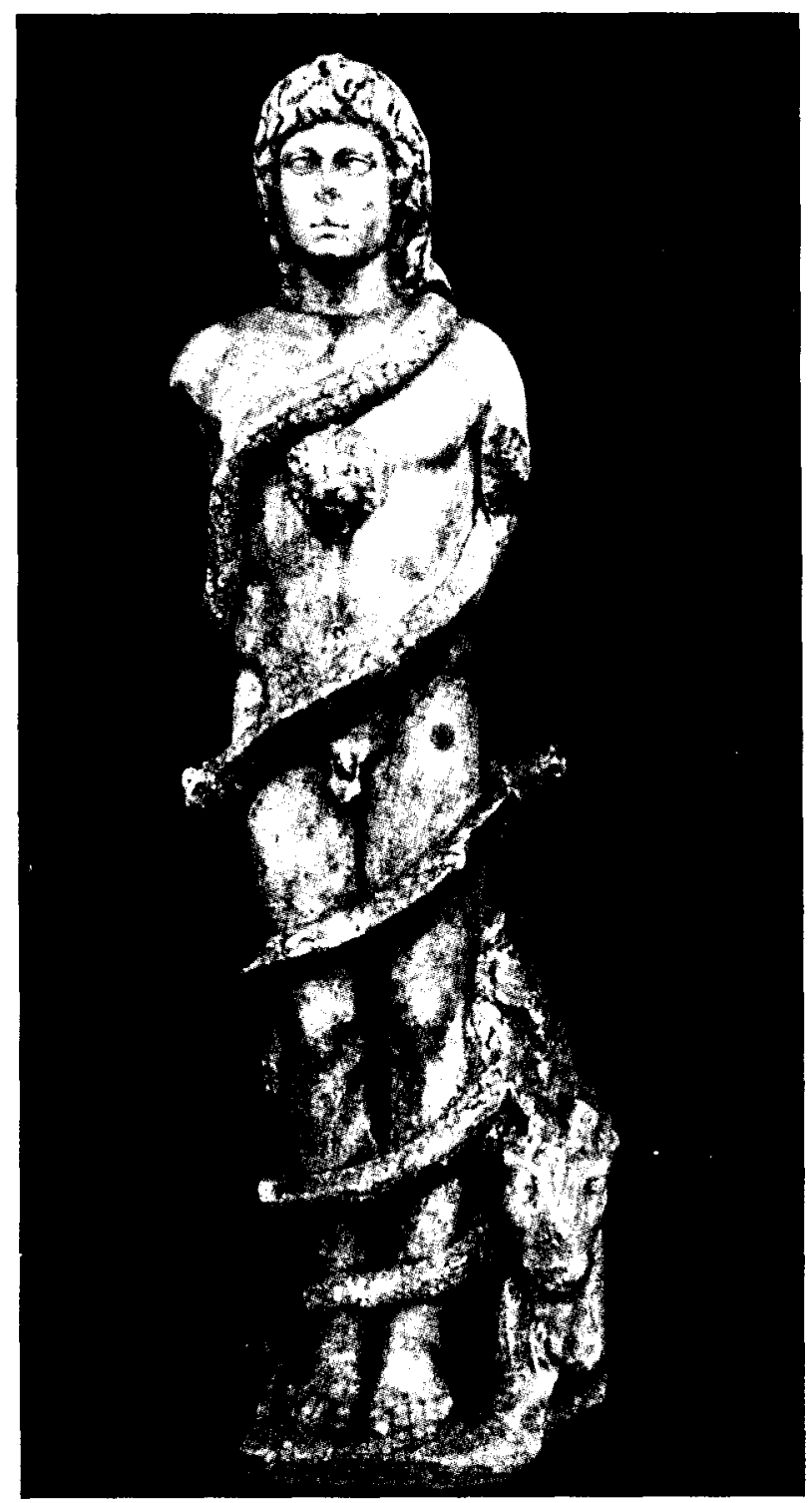

Fig. 11. Aion antropocéfalo de Mérida, rodeado por la serpiente y con la máscara leonina en el pecho. Museo Arqueológico de Mérida (Badajoz, España). 
Bendala parte del hecho de que «la forma más frecuente de representar a Mitra en el momento de brotar de la roca - saxigenus- lo muestra joven o niño, hundido todavía en la roca aproximadamente hasta la cintura, desnudo y con las manos en alto sosteniendo el cuchillo y la antorcha, todo ello con algunas variantes. Pero en bastantes ocasiones el dios sale casi totalmente de la roca, como si en conjunto tuviésemos una serie de secuencias que culminan en la mostración del cuerpo completamente exento" (M. Bendala, 1982: 108).

Siguiendo a Campbell (L. A. Campbell, 1968: 200), el citado autor escribe: «Es especialmente importante para nuestro caso contemplar la relación de este fenómeno con la presencia de la serpiente. Aparece ésta asociada a la piedra generatriz como agathos daimon, como serpiente pneumática que subraya su capacidad genética, idea que se expresa mostrando la roca rodeada por los anillos de la serpiente. Se advierte por otra parte, que esta simbología gozó de especial predilección en las regiones de Pannonia y Dacia, según puede verse en monumentos tan expresivos como los correspondientes al CIMRM 1492 - de Poetovio, en Pannonia - y al CIMRM 2134 - de Sarmizegetusa, en Dacia-. Pero aún más importante para nuestro propósito resulta comprobar que en algunas representaciones de Mitra saxigenus de la misma zona, la serpiente rodea no sólo la piedra sino también el cuerpo del dios" (M. Bendala, 1981: 295-296, figs. 4-5).

Bendala aporta dos ejemplos procedentes de Pannonia que considera los más claros: Carnuntum (CIMRM 1687) y Siscia (CIMRM 1472), asegurando que su cercanía tipológica o iconográfica con la figura emeritense es evidente (M. Bendala, 1981: 295-296, figs. 4-7; 1982: 108, figs. 4-7).

Para corroborar esta relación, el autor citado añade además otros datos. Según la interpretación expuesta, la imagen de Mérida parece indicar una veneración especial por Mithra naciente y también en esto existen nexos con la región de Pannonia. Campbell ha señalado ya que las dedicaciones a la petra genetrix, extremadamente raras, proceden casi en su totalidad de Pannonia, y que en relación con ello está incluso la existencia en Mérida de una inscripción dedicada al ara genesis por un frumentario de la Legio VII Gemina, vinculada, como bien se sabe, a la región de Pannonia. "La expresión aram genesis es una alusión peculiar, pero inequívoca de la petra genetrix" (M. Bendala, 1982: 108, núm. 26; L. A. Campbell, 1968: 276).

Sin negar, en principio, esta hipótesis sobre la identificación del antropocéfalo emeritense con Mithras saxigenus, conviene que, desde el 
punto de vista del presente artículo, hagamos tres puntualizaciones a la misma:

1. ${ }^{\text {a }}$ La posibilidad de hacer extensivo el concepto de agathos daimon a todas las serpientes mitraicas, como sería también nuestro deseo, es muy dudosa, incluso en los casos específicos de las representaciones de la petra genetrix. Turcan en su estudio del monumento mitraico descubierto en Lyon ya lo había señalado: "Le serpent n'est pas constamment associé au miracle de la petra genetrix. La frénquence de cette représentation se constate dans les provinces danubiennes, et si le relief était bien consacré a Mithra pétrogêne, ce témoignage confirmerait les relations de la métropole des Gaules avec ces régions du limes. Mais si le serpent n'est pas toujours lié au roc générateur, on peu douter qu'il en incarne la nature chthoniene" (R. Turcan, 1972: 20, n. 1; 1974: 160, n. 16). Y Turcan demuestra, además, que la serpiente no encarna el espíritu de la roca generatriz, ya que "le roc (infécond par définition) n'est pas la terre à proprement parler et reste étranger par nature à ses fonctions créatrices" (R. Turcan, 1974: 160).

2. La expresión petra genetrix no es equivalente a aram genesis ni en el caso de Mérida ni en ninguno otro, ya que se refiere, según nuestra opinión, en concreto, al ara conmemorativa que un iniciado $-M$. Valerius Secundus, en el caso de Mérida - dedica a la divinidad en agradecimiento por su iniciación, como es relativamente frecuente hacer, es decir, celebrar el «nacimiento" o «renacimiento» de una nueva vida, tras dicha iniciación, en las religiones que incluyen una mors voluntaria ritual $y$ un renacimiento tras ella. (renatus es el nombre que a veces recibe el iniciado mitraico) (J. Muñoz, 1989: 219, n. 188 y 720-725).

3. La admisión de influencias pannonias en estos testimonios arqueológicos mitraicos, sin otras evidencias contextuales, implicaria, una vez más, tener que admitir la hipótesis de la preponderancia del papel de las legiones romanas en la difusión del mitraísmo en Hispania, hipótesis insostenible no sólo para Lusitania (M. M. Alves, 1981: 33-39), sino para toda la Península Ibérica (J. Muñoz, 1989: 867-876; 1990: 153-170).

Volviendo ahora a la figura del leontocéfalo mitraico recordaremos que fue Zoëga quien primero propuso su equiparación con el Aion griego (G. Zoëga, 1808: 32 ss.). Cumont la admitió y perfeccionó, identificándolo además con el dios supremo de los iranios, Zervan-Akarana, dios del Tiempo Infinito (Fig. 12) (F. Cumont, 1984: 44 ss.; 1902: 90-92). Y ésta ha sido, en general, la interpretación aceptada hasta hoy, defendida, entre otros, por Vermaseren, máxima autoridad mundial en los Estudios Mitraicos hasta su fallecimiento (M. J. Vermaseren, 1963: 117 ss.). Frente 


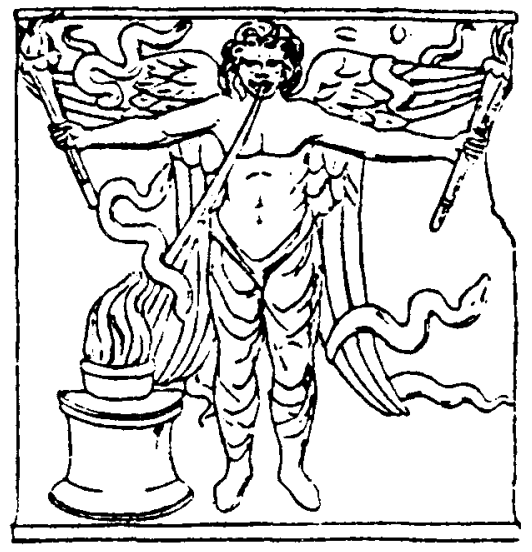

Fig. 12. Villa Colonna. Personaje mitraico leontocéfalo. Zervan? produciendo el viento y el fuego. CUMONT, Mithra II pág. 196; Eisler, Weltenmantel, II, pág. 445;

REINACH, Repertoire des reliefs $t$. III, pág. 219, 3.

a ella, algunos autores defienden la teoría de que el Leontocéfalo personifica a Ahrimán, el dios del Mal y de las Tinieblas, adorado como Deus Aeternus por los mismos mitraístas y al que incluso consagraron varias inscripciones votivas. Entre sus defensores destacan Duchesne-Guillemin (J. Duchesne-Guillemin, 1953: 126-129; 1958-60; 1962) y Zaehner (R. C. Zaehner, 1955a: VII-IX; 1955b; 1961: 129 ss.), a quienes ya se anticipó Legge en 1912 (I. F. Legge, 1912: 125- 142).

De la complejidad interpretativa del simbolismo de la serpiente en esta figura dan idea los comentarios de Will después de intentar localizar la procedencia de los tres rasgos distintivos más característicos de esta divinidad mitraica: la cabeza de león, los anillos de la serpiente y las alas (E. Will, 1955: 189). Para la cabeza de león o para las alas, el citado autor ha encontrado paralelos egipcios, pero no así para la serpiente: "Más delicado es el caso de la serpiente. No obstante, sobre una lami-

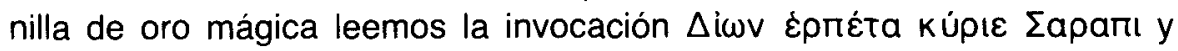
es bien conocida la pareja Sarapis-Aion, como también la de Aion-Agathodeimon, otro genio serpentiforme. Un papiro mágico nos revela un

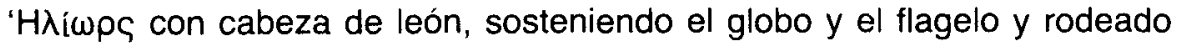
por la serpiente "ouroboros" (que "se muerde la cola") (Fig. 13); en fin sobre un amuleto de Vienne se ve un genio teriomorfo, medio hombre, medio león, con cuernos de carnero, con una serpiente en la mano ( $E$. Will, 1955: 190, n. 2. Sobre la serpiente "ouroboros", cfr. W. Deonna, 1952: 163-170). 
Fig. 13. La serpiente Ouroboros.

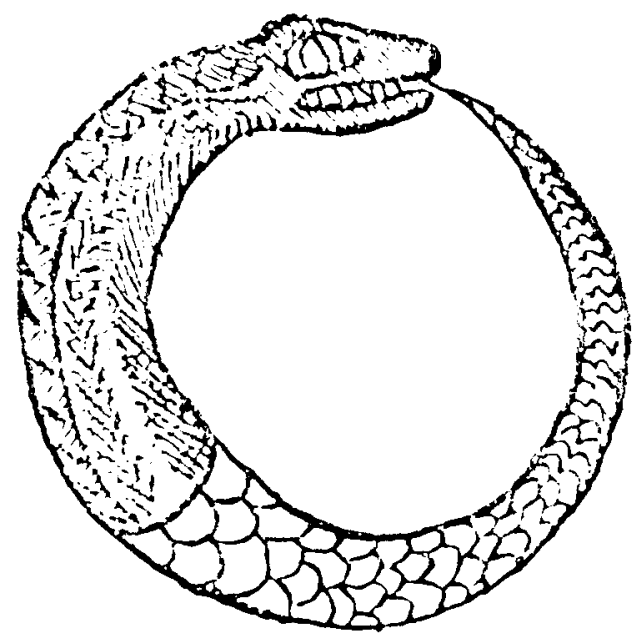

Pero, en definitiva, Will llega a la conclusión de que la imagen del Kronos-Aion mitraico conserva su carácter particular y no cuenta con antecedentes seguros ni en Siria ni en Egipto (E. Will, 1955: 191, ns. 24 , y 192, n. 1).

Desde nuestro punto de vista, la identificación de esta divinidad con Ahriman tendría la ventaja de poder conciliar el mitraísmo con el mazdeísmo en lo concerniente a la serpiente, criatura atribuida en la religión zoroástrica, como antes señalamos, al bestiario de Ahriman, dios del Mal y de las Tinieblas (J. Duchesne-Guillemin, 1960: 1-8; 1962: 256 ss.), pero no sólo el autor de esta hipótesis ha renunciado posteriormente a la misma (J. Duchesne-Guillemin, 1970: 685), sino que ha sido impugnada sistemáticamente por Widengren (G. Widengren, 1968: 260 ss.). Turcan, ante ambas opiniones, optar por señalar, de acuerdo con la simbología atribuida a la serpiente en este contexto cultual, que «el Aion mitraico reúne en su tipo plástico y en sus atributos las dos potencias necesariamente antinómicas del fuego: la vida y la destrucción de la misma; la vitalidad cósmica y solar, encarnada por la serpiente, y el Tiempo devorador, encarnado por el león. Este mismo fuego que anima al mundo lo destruirá para purificarlo al final de los tiempos. (R. Turcan, 1974: 166; 1989: 257-261).

De casi idéntica opinión es Hinnells, para quien el Leontocéfalo puede representar un ser cósmico que rige el curso de las almas a través de las esferas planetarias tras la muerte ( «the cosmic being who presides over the soul's ascent through the planetary spheres after death"), comparable a los Arcontes que presiden los diferentes pasos del acceso del 
alma al cielo en el pensamiento gnóstico; más concretamente, el Leontocéfalo estaria vinculado estrechamente al fuego (J. R. Hinnells, 1975b: 357).

4. El extraordinario desarrollo registrado por los Estudios Mitraicos en las últimas décadas ha determinado un cambio radical en muchas de las hipótesis hasta ahora sustentadas. En este nuevo panorama ha sido la interpretación de la Tauroctonia desde un punto de vista astronómico lo que ha supuesto el cambio más notable en cuanto a la aproximación al conocimiento de esta doctrina. En parte, se trata de un retorno a teorías precumontianas que veian en esta escena los símbolos de los fenómenos y ciclos naturales, teorías cuyas últimas consecuencias todavía hoy no se han alcanzado, pero que están desafiando el supuesto establecido de que la Tauroctonía ha de interpretarse primero y principalmente como un episodio de un relato mítico, y proponiendo su interpretación como reproducción de un mapa del cielo.

Esta novedad interpretativa se basa en la coincidencia que presenta la extraña agrupación de elementos iconográficos que componen la citada escena con un determinado conjunto de constelaciones (toro con Taurus, perro con Canis maior y/o minor, serpiente con Hydra, león con Leo, crátera con Cráter, cuervo con Corvus, escorpión con Scorpius y el manojo de espigas del extremos de la cola del toro con la estrella Spica (R. Beck, 1984: 2081). Cumont, basándose en las investigaciones ya citadas, de Stark, había notado estas mismas correspondencias, pero no las tuvo en cuenta, considerándolas adornos superficiales y triviales en comparación con un significado más profundo de la Tauroctonia (Fig. 14). (F. Cumont, 1899: 202) en la que llegó a distinguir, por un lado, la serpiente y el escorpión, criaturas maléficas de Ahriman, que intentan frustrar los efectos benéficos del sacrificio del toro; por otro, el perro, fiel compañero de Mithra (F. Cumont, 1988: 190-192). Sin embargo, según Beck, es fácil deducir del estudio de esta escena que los comportamientos de ambos animales corren parejos (Fig. 15) (R. Beck, 1984: 2080).

Beck, por ejemplo, basándose en un texto de contenido astrológico atribuido a Zoroastro y recogido por Plinio $(H N, 18,55)$, ya habia sugerido la existencia de una asociación entre el escorpión, representado en la Tauroctonia y la siembra del grano (R. Beck 1976: 6; 1984: 2080, n. 123).

Pero, sobre todo, ha sido este mismo autor quien ha establecido para la Tauroctonia el citado sistema de correspondencias celestes, planetarias, descubierto con motivo de una investigación anterior basada en la aplicación de un criterio astronómico a las figuras de los dadóforos 


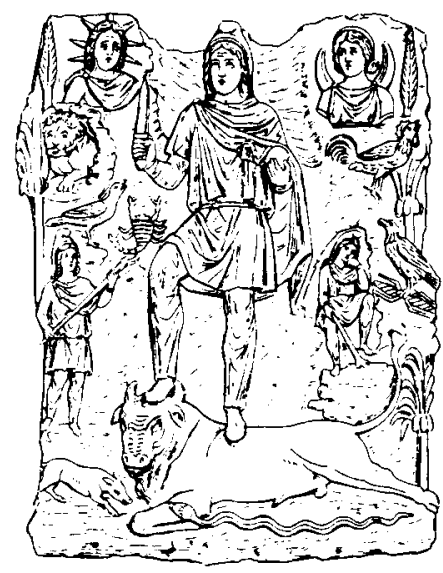

Fig. 14. Relieve mitraico. Villa Altieri (convertida en prisión). Cumont, Mithra $t$. Il pág. 221 fig. 131; REINACH, Répertoire des réliefs $t$. III pág. 157 pág. 157, 2. Obsérvense los diversos elementos: Sol-Luna, también León, Gallo, Escorpión, águila, palmas, etc.. también Cautes y Cautopates.

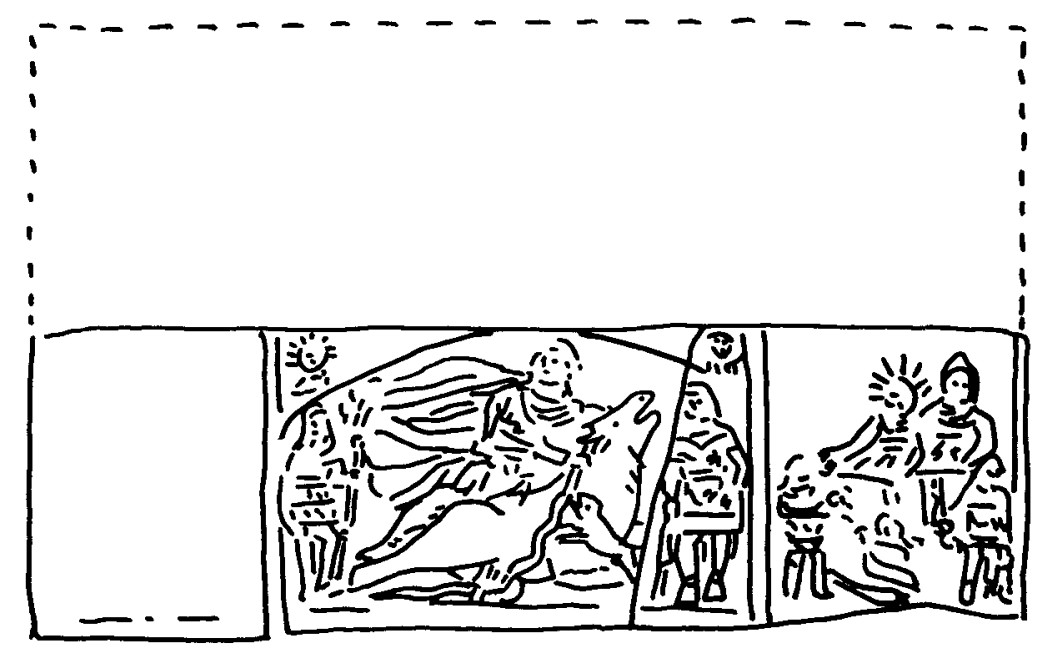

Fig. 15. Reconstrucción parcial e ideal por $G^{a}$ y Bellido del retablo mithraico de Troia (Portugal). 
Cautes y Cautopates (R. Beck, 1977: 9 ss., sobre un documento inédito del mismo autor de 1973). Al analizar la dependencia astronómica y astrológica de la Tauroctonía, Beck señala que "los elementos de la Tauroctonia están determinados, en primer lugar, sobre otras bases y dentro de un sistema coherente de correspondencia, el de las constelaciones" (R. Beck, 1984: 2092). Por ello, para este autor, la iconografía mitraica, especialmente la de la escena citada, es vehículo de un sofisticado y complejo simbolismo astronómico, y las estructuras de los Misterios de Mithra - no únicamente la del mitreo, como ya había señalado Porfirio (De Antro Nympharum, 6) - son también, en sus diferentes aspectos, desde los iconográficos hasta los referentes a la estructura iniciática en grados, imágenes del cosmos («images of the cosmos") (R. Beck, 1984: 2061, n. 90). Sin olvidar, además, que «no se puede dar por sentado que para cada símbolo o grupo de símbolos en una escena haya un solo significado". (R. Beck, 1984: 2059).

Aclararemos - Beck no lo hace - que este planteamiento tampoco implica que esos significados tengan que ser contradictorios entre sí, cosa que nos conduciría de nuevo a los ya mencionados planteamientos dualísticos de Cumont. Con indudable acierto Beck explica: «Mysteries are about celestial salvation, and for their picture of the heavens, in which and through which salvation is achieved, the cult necessarily drew on and adapted what Graeco-Roman science made available to them" (R. Beck, 1984: 2061, n. 91).

La exposición de todo este complejo, pero sugestivo, planteamiento excedería los límites del presente artículo, pero no podemos pasar por

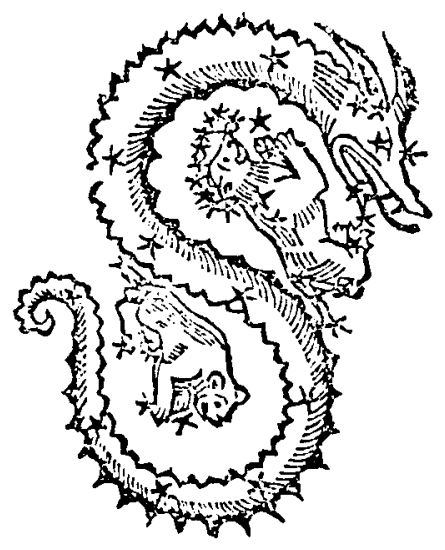

Fig. 16. La Osa Mayor, la Osa Menor y el Dragón. Champean, G.: Introduction au monde des symboles Paris 1966. 
alto el simbolismo reservado en él a la serpiente. Según Beck, «la serpiente es, principalmente, un simbolo del intrincado camino que conduce desde el Sol hasta la Luna y de sus reuniones en conjunciones y eclipses dentro del Zodiaco (también es, aunque discutible, un importante elemento en la doctrina de los Misterios, especialmente en la teoría de la génesis). El citado autor corrobora esta interpretación, aduciendo el hecho de que un eclipse total de Sol en Leo - que es donde se coloca la cabeza de la serpiente pintada en el techo del Mitreo de Santa Ponzaera visible en esta localidad en una fecha determinada (14 de agosto de 212 d.C.), fecha comprendida en el período en el que se supone que este mitreo se construyó, sugiriendo, en consecuencia, que el Zodiaco representado en el techo de dicho mitreo conmemora este eclipse (R. Beck, 1984: 2021-2022).

De la teoría de Cumont formaba parte la idea de que un substrato astrológico, de origen babilónico, encubría a menudo un significado doctrinal iranio interno. Y como ejemplo particular estaba el grupo león-crátera-serpiente, que aparece en varias posiciones en las complejas tauroctonías nórdicas, cuyo simbolismo ha sido explicado de maneras diversas. Recientemente parece haber aumentado entre los investigadores la conciencia de la existencia de una multivalencia de la iconografía mitraica en general, quizá motivada por el influjo de estas interpretaciones astronómicas que obligan a considerar la existencia de todo un orden diferente de significados junto a aquellos otros ya conocidos con anterioridad ( $R$. Beck, 1984: 2054).

Fundamentalmente, los Misterios de Mithra conciernen, según Beck, a la salvación celestial, y para acceder a la representación de este cielo nada mejor que las imágenes que del mismo aportaba la ciencia grecoromana de la época. Quizá no se trate más que de una conciencia de la debilitación, en las décadas pasadas, de lo que se tenía como terminada estructura irania de los Misterios, con la entrada en juego de esta nueva teoría, cuyo contenido está inspirado en una parte considerable por la astronomía y la astrología.

Por lo que respecta a la asociación del Leontocéfalo con el Tiempo, que pocos negarian hoy, tanto si le identifican o no con Aion, Beck sugiere su conexión incluso con Saturno a través de las notorias equivalencias griegas de Khronos con chronos. La serpiente que rodea al dios con sus anillos es un símbolo del Tiempo (R. Beck, 1978: 107-116), especialmente cuando, como en el torso de Arles (879), se enrosca en el Zodiaco. Como símbolo del Tiempo, según el Tercer Mitógrafo Vaticano (texto en F. Cumont, 1899: 53), forma parte de la iconografía de Saturno. 
Beck hace especial hincapié en esta conexión con Saturno (también reafirmada por Cumont, 1899: 77 ss.), porque, "dado que sabemos algo del lugar que ocupaba Saturno en el ámbito del culto (ver esp. Vermaseren, 1951: 292 ss.), la serpiente puede ofrecernos una aproximación indirecta al enigmático papel del dios leontocéfalo en los Misterios de Mithra" (R. Beck, 1984: 2087, n. 131).

5. Así pues, y teniendo en cuenta las reflexiones apuntadas, en nuestra opinión, para el estudio del significado de las representaciones de serpientes en la iconografía mitraica, habrá que tener en cuenta, entre otros, los siguientes hechos:

- En el contexto cultual greco-romano, la serpiente mitraica, especialmente en la Tauroctonía, podria simbolizar toda una variedad de fuerzas benefactoras: la tierra, los dioses, la relación con los mismos o su favor y protección, la fertilidad, la salud, la fecundidad y también el difunto y su heroización. Sin embargo, no es segura su plena adscripción a este contexto.

- El simbolismo iconográfico de la serpiente podría proceder de una mezcla de contextos interpretativos cultuales greco-romanos o grecoorientales, pasando desde las más sencillas a las más complejas interpretaciones.

- En todas las escenas y figuras mitraicas representadas iconográficamente, el significado de la serpiente, aunque pueda ser polivalente, no parece que pueda interpretarse desde el punto de vista dualístico zoroástrico de la contraposición entre el Bien y el Mal.

- La función de la representación de la serpiente en la iconografía mitraica no parece ser nunca independiente o autónoma, sino formar parte de todo un compejo sistema conceptual.

- Las más recientes investigaciones establecen un sistema de correspondencias o equivalencias astronómicas, determinado por la evolución de los esquemas científicos greco-romanos de la época, cuyas últimas consecuencias todavía hoy no se han establecido, y en el que la serpiente desempeña una función especifica.

- La serpiente es un símbolo polivalente y su presencia en el mundo mitraico responde a esta realidad. En todo el mundo antiguo (Babilonia, Egipto, Fenicia, Canaan, Grecia-Roma), a una realidad física evidente de "venenosa" se opone su carácter benéfico y protector. $Y$ puesto que existen diversos niveles de iniciados mitraicos, con diferencias intelectuales grandes, y puesto que estos iniciados fueron muy varia- 
dos social y geográficamente, habria que distinguir la existencia de:

a) Un concepto de serpiente para los devotos mitraicos pertenecientes a la élite intelectual, culta, que elabora la doctrina y la iconografía (tal vez diferente, a su vez, en medios geográficos distintos), en consonancia con los avances de la ciencia de la época.

b) Otro concepto de serpiente para los devotos mitraicos de las clases inferiores, con inquietudes intelectuales muy limitadas, para los que todo era "mágico" y apotropaico.

Pero, en nuestra opinión, la interpretación del significado de la serpiente en la iconografía mitraica es un tema que, como tantos otros en el campo de los Estudios Mitraicos, debemos mantener, todavía, necesariamente abiertos, teniendo en cuenta las múltiples posibilidades a las que su variado significado parece conducirnos. 


\section{BIBLIOGRAFÍA}

AmAND, M., 1970: “Notes sur le culte du serpent criocéphale dans la cité des Nerviens", en Latomus, XXIX, 1970, págs. 340-347.

- 1975: "Les vases mithriaques aux serpents dans l'Empire romain", en Colloque International d'Archéologie tenu à Rouen du 3 au 5 juillet 1975 (Ponencia resumida por R. TURCAN, 1977: 181).

- 1984: Vases à bustes, vases à décor zoomorphe et vases cultuelles aux serpents dans les anciennes provinces de Belgique et de Germanie, Academia Royale de Belgique, Mémoires de la Classe de Beaux-Arts, Bruxelles, 1984.

ALVES, M. M., 1981: "Os cultos orientais em Pax lulia, Lusitania", en Memorias de Historia Antigua, V (1981), Oviedo, págs. 33-39.

BIANCHI, U., 1979: «Prolegomena: The religio-historical question of the Mysteries of Mithra", Mysteria Mithrae (Proceedings of the International Seminar on the Religio-Historical Character or Roman Mithraism with particular Reference to Roman and Ostian Sources. Rome and Ostia, 28-31 March, 1978), Leiden, 1979, págs. 3-60.

- 1984: "La tipologia storica dei misteri di Mithra", en Aufstieg und Niedergang der Römischen Welt, Band II, 17, Religion, Berlin-New York, 1984, págs. 2116-2134.

BECK, R., 1976: "Interpreting the Ponza Zodiac", en Journal of Mithraic Studies, 1, London, 1976, págs. 1-9.

- 1977: "Cautes and Cautopates: some astronomical considerations", Journal of Mithraic Studies, 2, págs. 1-17.

- 1984: "Mithraism since Franz Cumont», Aufstieg und Niedergang der Römischen Welt, Band II, 17.4, Berlin-New York, 1984, págs. 20022115.

BENDALA, M., 1981: "Las religiones mistéricas en la España romana", en Symposio sobre La religión romana en Hispania, Madrid, 1979, págs. 283-299. 
- 1982: "Reflexiones sobre la iconografía de Mérida", en Homenaje a don José Alvarez y Sáenz de Buruaga, Madrid, 1982, págs. 99-108.

Bru Romo, M. y VazQuez HoYs, A. M., 1982: "The representation of the Serpent in Ancient Iberia", en Archaeology and fertility cult in the Ancient Mediterranean, Malta, 1986, págs. 305-314, láms. 349-356.

CAmpbell, L. A., 1954-55: "Typology of Mithraic Tauroctones", Berytus, vol. XI, 1954-55, Copehaguen, págs. 1-60.

- 1968: Mithraic Iconography and Ideology, Leiden, 1968.

CumONT, F., 1896: Textes et Monuments figurés relatifs aux Mystéres de Mithra, vol. 2, Bruxelles, 1896.

- 1899: Textes et Monuments figurés relatifs aux mystères de Mithra, vol. 1, Bruxelles, 1899.

- 1902: Les mystères de Mithra, Paris, 1902.

- 1912, reimp. 1960, en Nueva York: Astrology and Religion among Greeks and Romans, New York, 1960.

- 1975: "The Dura Mithraeum", Mithraic Studies, Manchester, 1975, págs. 151-213.

DeONNA, W., 1952: "Ouroboros", en Artibus Asiae, 15, págs. 163-170.

DuCHESNe-Guillemin, J., 1953: Ormazd et Ahriman, Paris, 1953, páginas 126-129.

- 1958-60: Aion et le Léontocéfale, Mithras et Ahriman, La Nouvelle Clio, 10, Paris.

- 1962: La religion de I'Iran ancien, Coll "Mana", Paris, 1962.

- 1970: Encycl. de la Pléiade, Hist. des Religions, I, Paris, 1970, página 685.

Dussaud, R., 1950: “Le dieu mithriaque léontocéphale», Syria, XXVII, págs. 253-260.

GalL, H. von, 1978: The Lion-Headed and the Human-Headed God in the Mithraic Mysteries, Acta Iranica, IV, 17, Leiden, 1975, págs. 215-277.

GaRCíA Y Bellido, A. 1948: "El culto a Mithras en la Península Ibérica", en Boletín de la Real Academia de la Historia, CXXII, cuad. I, 1948, págs. 283-349, 18 láms. y 22 fotografías.

- 1967: Les religions orientales dans l'Espagne romain, Leiden, 1967. Harrison, J., 1963: Themis, London, 1963.

HELDENBERGH, R., 1976: "Tourinnes-Saint Lambert. Un vicus gallo-romain. Vase à buste et à décor zoomorphe", en Latomus, 35, 1976, págs. 522 y ss. y figs. 3 y 6 .

HiNnELLS, J. R., 1975a: "Reflections on the Bull-slaying scene", en Mithraic Studies, Manchester, 1975.

- 1975b: "Reflections on the Lion-headed figure in Mithraism", Acta Iranica, Ser. 2, vol. 1, Leiden, 1975, págs. 333-369. 
LEGGE, I. F., 1912: "The Lion-headed God of the Mithraic Mysteries", en Proc. of the Society of Biblical Archaeology, Núm. 34, 1912, págs. 125-142, y Núm. 37, págs. 151-152.

LeISEgang, H., 1955: "The Mystery of the Serpent" [1939], The Mysteries, Bollingen Series, XXX-2, Papers from Eranos Yearbooks, Princeton University Press, 1955, págs. 194-260.

LEVI, D., 1944: “Aion", Hesperia, 13, págs. 73 y ss.

LOMMEL, H., 1949: "Mithras und das stieropfer», Paideuma, III, 1949.

MELIDA, J. R., 1914: "Cultos emeritenses de Serapis y de Mithras", en Boletín de la Real Academia de la Historia, 1914, Madrid, págs. 439456, con 7 láms.

Mitropoulou, E.: Gods and Heros in the form of snake. Athens, 1975.

MuÑOz, J., 1989: El culto de Mithra en Hispania: caracteres especificos (tesis doctoral inédita), UNED, Madrid, 1989.

- 1990: "Evidencias mercantiles en contextos arqueológicos mitraicos", en Espacio, Tiempo y Forma, Serie II, 1, 1990, Madrid, páginas 153-170.

- 1991: "Vasos litúrgicos mitraicos", en Espacio, Tiempo y Forma, Serie II, $\mathrm{H}^{\text {a }}$ Antigua, t. 4, 1991 (en prensa).

Ristow, G., 1974: Mithras in römischen Köln, EPRO, 42, Leiden, 1974.

- 1975: Religionen und ihre Denkmaler im antiken Köln, Colonia, 1975.

SAXL, F., 1931: Mithras, Typengeschichtliche Untersuchungen, Berlín, 1931.

SfamenI GasparRo, J., 1979a: «ll mitraismo nell'ambito della fenomenologia misterica", Mysteria Mithrae, Leiden, 1979, págs. 299-248.

- 1979b: "Riflessioni ulteriori su Mithra dio "místico"», Mysteria Mithrae, Leiden, 1979, págs. 397-408.

STARK, K. B., 1865: Zwei Mithräen, 1865.

Strong, E., 1937: “Terra Mater or Italia?», The Journal of Roman Studies, XXVI, 1937, London, págs. 114-126.

SwOBODA, E., 1937: "Die Schlange im Mithraskult", Jahreshefte des österreichischen Archäologischen Instituts, XXX, Wien, 1937, págs. 1-27.

TURCAN, R., 1974: “La serpent mithriaque à Lyon», Revue archéologique de l'Est et du Centre-Est, XXV, Dijon, 1977, págs. 155-166.

- 1989: Les cultes orientaux dans le monde romain, Paris, 1989.

- 1976: "Chronique gallo-romain", en Journal of Mithraic Studies, Vol. I, núm. 2, London, págs. 176-183.

- 1977: “Chronique gallo-romain», en Journal of Mithraic Studies, Vol. II, núm. 2, London, págs. 176-223. 
VÁzouez HoYs, A. M., 1981: «La serpiente en el mundo antiguo. I. La serpiente en las religiones mediterráneas", en Boletín Asociación Española Amigos de la Arqueología, 14, 1981, Madrid.

- 1981: "Cultos y ritos de fecundidad y su simbología: Las aguas en la Hispania romana", Universidad y Sociedad, I, 1981, Madrid, páginas 167 y ss.

- "Los cistóforos y su significado", colab. junto con Fernandez URiel, P., Boletín de la Asociación Española de Amigos de la Arqueología, n. 29, julio-diciembre 1990, págs. 48-61.

- "La serpiente en las monedas griegas", /l Congreso de la Asociación Arys, Jarandilla, dic. 1990, en prensa.

- "Aproximación a los cultos a la serpiente en Egipto: Isis-Thermouthis-Sarapis-Agathodaimon", Homenaje a F. Presedo. Universidad de Sevilla. En prensa. Col. con Poyato Holgado, C.

- "La que ama el silencio: Sobre la serpiente en Egipto", Espacio, Tiempo y Forma, Serie II, n. ${ }^{\circ} 4,1991$. En prensa.

- "La serpiente en el Egipto Antiguo", Estudios sobre Egipto en la Antigüedad. Universidad de Alcalá de Henares. En prensa.

Vermaseren, M. J., 1950-1960: Corpus Inscriptionum et Monumentorum Religionis Mithriacae, I-II, La Hague Comitis, 1950-60.

- 1963: Mithras, the Secret God, London, 1963.

- 1975: “A magical Time god", en Mithraic Studies, II, Manchester, 1975, págs. 446-456.

VERTET, H., 1965: "Les représentations mithriaques sur les vases d'argile en Gaul", Actes du $88^{\mathbf{e}}$. Congrés National des Sociétés Savantes, Clermont-Ferrand, 1963, Paris, 1965.

WidengRen, G., 1968: Les religions de I'Iran, París, 1968.

WILL, E., 1955: Le relief cultuel gréco-romain. Contribution à I'Histoire de l'Art de l'Empire romain, Paris, 1955.

ZAEHNER, R. C., 1955a: Zurvan a Zoroastrian dilema, Oxford, 1955.

- 1955b: «Proscrip to Zurvan», BSOAS, 17, 1955.

- 1961: The Dawn and Twilight of Zoroastrianism, Oxford, 1961, páginas 129 y ss.

ZOËGA, G., 1808: Bassi-rilievi antichi di Roma, II, Rome, 1808. 